\title{
Dehydration activates an NF- $K B$-driven, COX2-dependent survival mechanism in renal medullary interstitial cells
}

\author{
Chuan-Ming Hao, ${ }^{1,2}$ Fiona Yull, ${ }^{3}$ Timothy Blackwell, ${ }^{4}$ \\ Martin Kömhoff, ${ }^{1}$ Linda S. Davis, ${ }^{1}$ and Matthew D. Breyer ${ }^{1,2,5,6}$ \\ ${ }^{1}$ Division of Nephrology, Department of Medicine, \\ ${ }^{2}$ Vanderbilt George M. O’Brien Kidney and Urologic Diseases Center, \\ ${ }^{3}$ Department of Cell Biology, and \\ ${ }^{4}$ Division of Allergy, Pulmonary, and Critical Care, Department of Medicine, Vanderbilt University School of Medicine, \\ Nashville, Tennessee, USA \\ ${ }^{5}$ Veterans Administration Medical Center, Nashville, Tennessee, USA \\ ${ }^{6}$ Department of Molecular Physiology and Biophysics, Vanderbilt University School of Medicine, Nashville, Tennessee, USA
}

Address correspondence to: Chuan-Ming Hao, F-427 ACRE Building, Veterans Administration Medical Center, Nashville, Tennessee 37212, USA. Phone: (615) 327-4751 ext. 5492; Fax: (615) 343-4704; E-mail: chuanming.hao@mcmail.vanderbilt.edu.

Received for publication March 24, 2000, and accepted in revised form August 31, 2000.

Renal prostaglandin (PG) synthesis is mediated by cyclooxygenase- 1 and -2 (COX1 and COX2). After dehydration, the maintenance of normal renal function becomes particularly dependent upon PG synthesis. The present studies were designed to examine the potential link between medullary COX1 and COX2 expression in hypertonic stress. In response to water deprivation, COX2, but not COX1, mRNA levels increase significantly in the renal medulla, specifically in renal medullary interstitial cells (RMICs). Water deprivation also increases renal NF- $\mathrm{kB}$-driven reporter expression in transgenic mice. NF- $\mathrm{kB}$ activity and COX2 expression could be induced in cultured RMICs with hypertonic sodium chloride and mannitol, but not urea. RMIC COX2 expression was also induced by driving NF- $\kappa B$ activation with

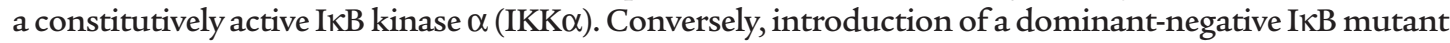
reduced COX2 expression after hypertonicity or IKK $\alpha$ induction. RMICs failed to survive hypertonicity when COX2 was downregulated using a COX2-selective antisense or blocked with the selective nonsteroidal anti-inflammatory drug (NSAID) SC58236, reagents that did not affect cell survival in isotonic media. In rabbits treated with SC58236, water deprivation induced apoptosis of medullary interstitial cells in the renal papilla. These results demonstrate that water deprivation and hypertonicity activate NF- $\mathrm{kB}$. The consequent increase in COX2 expression favors RMIC survival in hypertonic conditions. Inhibition of RMIC COX2 could contribute to NSAID-induced papillary injury.

J. Clin. Invest. 106:973-982 (2000).

\section{Introduction}

The ability of the kidney to generate a medullary interstitial tonicity exceeding $1,000-3,000 \mathrm{mOsm} / \mathrm{kg}$ is critical for the generation of a concentrated urine. Cells residing in this harsh environment must not only survive rapid changes in sodium chloride $(\mathrm{NaCl})$ and urea concentration associated with changing states of hydration, but also function normally. The mechanisms allowing renal medullary cells to survive osmotic stress are only partially characterized. Hypertonic stress is associated with transcriptional activation of heat shock proteins, as well as several genes that facilitate the accumulation of nontoxic intracellular osmoles, including aldose reductase (AR), the betaine transporter (BGT1), and the sodium-dependent myo-inositol transporter (SMIT-1) $(1,2)$. The induction of these genes by hypertonicity involves the activation of members of the MAP kinase family, including c-Jun $\mathrm{NH}_{2}$-terminal kinase (JUNK) and p38 MAP kinase $(3,4)$. Alternatively, binding of as yet uncharacterized transactivating factor(s) to a specific osmotic response element (ORE) has be shown to be crucial for the induction of $\operatorname{AR}(5,6)$. Recently, a tonicity response enhancer (TonE) transactivating binding protein (TonEBP) has also been identified as playing an important role in regulating expression of BGT1 and AR genes after hypertonic stress $(7,8)$. Enhanced expression of these genes appears to be a crucial mechanism that facilitates adaptation of medullary cells to the hypertonic environment (2).

Prostaglandin-forming cyclooxygenases (COXs) may represent an additional class of genes that promote medullary interstitial cell viability (9). Renal medullary prostaglandins (PGs) are thought to play a critical role in maintaining renal medullary blood flow, and inhibition of cyclooxygenase with nonsteroidal anti-inflammatory drugs (NSAIDs) has been associated with necrosis of the papilla, especially after dehydration (10). Renal medullary COX expression is increased by water restriction $(11,12)$. Both COX1 (11) and COX2 expression (12) have been reported to increase in renal papillae of waterdeprived rats, although the site of this induction is 
unclear. Those studies also suggest that increased osmolality directly induces COX2 expression in cultured renal epithelial Madin-Darby canine kidney (MDCK) cells collecting duct cells (mIMCD-K2) (11, 12). However, other studies suggest medullary COX2 is restricted to interstitial cells and not expressed in collecting ducts $(13,14)$. COX2 gene expression may be regulated by cytokines through multiple signaling mechanisms, including the MAP kinase and NF- $\mathrm{KB}$ pathways, in a cell-specific manner (15-17). The mechanisms by which tonicity regulates $\mathrm{COX} 2$ expression in the renal medulla are not established. The present studies were designed to examine the significance and mechanism(s) of COX2 induction in the renal medulla after water deprivation. The role of COX2 in maintaining viability of cells in the renal medulla was also examined.

\section{Methods}

Animal studies. The effect of water deprivation on renal COX2 expression was examined in mice and New Zealand white rabbits. Seven rabbits were placed in metabolic cages and allowed free access to $5 \%$ sucrose water $(n=4)$ or subjected to water deprivation $(n=3)$. Animals were allowed free access to food. Twentyfour-hour urine was collected to determine osmolality. Seventy-two hours later, the animals were sacrificed. The left kidney was processed for in situ hybridization. The right kidney was separated into cortical and medullary portions, and total RNA was extracted.

To examine the effect of COX2 inhibition on renal medullary interstitial cell (RMIC) survival in vivo, nine New Zealand white rabbits were treated with $(n=4)$ or without $(n=3)$ the COX2 inhibitor SC58236 for 10 days followed by water deprivation (72 hours), or SC58236 alone without water deprivation $(n=2)$. SC58236 was orally administrated at $10 \mathrm{mg} /$ day as a suspension in $0.5 \%$ methylcellulose, $0.025 \%$ Tween-20. After treatments, rabbits were sacrificed, and left kidneys were perfused, fixed, and paraffin embedded. Apoptotic cells were examined using the terminal deoxynucleotidyl transferase-mediated dUTP nick-end labeling (TUNEL) assay (18), according to manufacturer's instruction (DeadEnd Colorimetric Apoptosis Detection System; Promega Corp., Madison, Wisconsin, USA).

The effect of water deprivation on renal NF- $\kappa \mathrm{B}$ activation in vivo was examined in transgenic mice expressing a luciferase reporter driven by a NF- $\mathrm{KB}$ response promoter (HIV long-terminal repeat [LTR] luciferase [HLL] mice) (19). HLL mice were either allowed free access to $5 \%$ glucose water $(n=8)$ or restricted from drinking water for 24 hours $(n=8)$. The left kidneys were removed for determination of luciferase activity using a commercial luciferase assay system, according to manufacturer's protocol (Promega Corp.). Luciferase activity was quantified using a luminometer (Monolight 3010; PharMingen, San Diego, California, USA) and adjusted for the amount of protein. Total RNA was extracted from the right kidneys. The bladder urine was collected for determination of urinary osmolality.

Cell culture. Rabbit medullary interstitial cells were cultured as described previously (9). Briefly, female New Zealand white rabbits were anesthetized (44 $\mathrm{mg} / \mathrm{kg}$ ketamine and $10 \mathrm{mg} / \mathrm{kg}$ xylazine, intramuscularly). The left kidney was removed, and the medulla was dissected and minced with a razor blade under sterile conditions in $5 \mathrm{ml}$ of sterile RPMI-1640 plus $10 \%$ (vol/vol) FBS (HyClone Laboratories, Logan, Utah, USA). This homogenate was injected subcutaneously in the abdominal wall using a 14-gauge needle. Twenty days after surgery, subcutaneous nodules appeared. The rabbits were reanesthetized and sacrificed by decapitation, and the nodules were removed under sterile conditions. Nodules were minced into 1 - $\mathrm{mm}$ fragments and explanted in $75-\mathrm{cm}^{2}$ tissue culture plates. Cells were cultured in RPMI-1640 tissue culture medium supplemented with $10 \%$ (vol/vol) FBS, and streptomycin and penicillin. Cultures were incubated at $37^{\circ} \mathrm{C}$ in $95 \% \mathrm{O}_{2} / 5 \% \mathrm{CO}_{2}$. Tissue culture medium was changed every $48-72$ hours. Cells were studied in their third to fourth passage. These cells exhibit characteristic abundant oil red-O-positive lipid droplets, which typifies type I RMICs.

Mouse RMICs were prepared as reported previously (20). HLL mice were sacrificed, and the kidneys were rapidly removed and washed in Ringer's solution. The renal medulla was excised, minced, and placed in Ringer's solution containing collagenase $(1 \mathrm{mg} / \mathrm{ml})$ at $37^{\circ} \mathrm{C}$ for 1 hour with occasional agitation. The collagenase-treated tissue was then washed in DMEM three times and cultured in DMEM containing 20\% FBS. The FBS concentration was switched to $10 \%$ after the cells reached confluence. The cells were studied after 3 to 4 passages. Oil red-O staining demonstrated abundant lipid droplets characteristic of RMICs.

Immunoblotting. COX1 and COX2 immunoblots were performed on whole-cell lysate from cultured RMICs. Protein concentration was determined using the bicinchoninic acid protein assay (Sigma, St. Louis, Missouri, USA). Thirty micrograms of protein extract was loaded in each lane of a $10 \%$ SDS-PAGE mini-gel and run at $120 \mathrm{~V}$. Protein was transferred to a nitrocellulose membrane at $22 \mathrm{~V}$ overnight at $4^{\circ} \mathrm{C}$. The membrane was washed three times with TBST (50 mM Tris, pH 7.5, $150 \mathrm{mM} \mathrm{NaCl}, 0.05 \%$ Tween$20)$ and then incubated in blocking buffer $(150 \mathrm{mM}$ $\mathrm{NaCl}, 50 \mathrm{mM}$ Tris, $0.05 \%$ Tween-20, and 5\% Carnation nonfat dry milk, $\mathrm{pH}$ 7.5) for 1 hour at room temperature. The membrane was then incubated with an anti-human COX2 (sc-1745, 1:300; Santa Cruz Biotechnology Inc., Santa Cruz, California, USA) or an anti-COX1 (sc-1752, 1:300; Santa Cruz Biotechnology Inc.) Ab in blocking buffer overnight at $4^{\circ} \mathrm{C}$. After washing (three times), the membrane was incubated with a horseradish peroxidase-conjugated secondary $\mathrm{Ab} \quad(1: 20,000$, Jackson ImmunoResearch Laboratories, West Grove, Penn- 
sylvania, USA) for 1 hour at room temperature, followed by three 15 -minute washings. Ab labeling was visualized by addition of chemiluminescence reagent (Renaissance; DuPont NEN Life Science Products, Boston, Massachusetts, USA), and the membrane was exposed to Kodak XAR-5 film (Eastman Kodak Co., Rochester, New York, USA).

Nuclease protection. A 356-bp riboprobe for nuclease protection was generated from a portion of the $3^{\prime}$ coding region of the rabbit COX2 cDNA (14), and a 418 -bp riboprobe was generated from an untranslated region of mouse COX2 PCR fragment. A 250-bp riboprobe was generated from a PCR fragment of rabbit $\beta$-actin. Antisense cRNA was transcribed from the flanking T7 promoters from the cDNA in the presence of $\left[\alpha-{ }^{32} \mathrm{P}\right]-\mathrm{UTP} 400-800 \mathrm{Ci} / \mathrm{mmol}$ (MAXIscript; Ambion, Austin, Texas, USA). Antisense RNA $\left(1.5 \times 10^{5} \mathrm{cpm}\right.$ for COX2) was hybridized to $30 \mu \mathrm{g}$ of total cellular RNA at $42^{\circ} \mathrm{C}$ for $14-18$ hours. In all cases total cellular RNA was prepared using chloroform/phenol extraction (21) using commercial reagents (Molecular Research Center Inc., Cincinnati, Ohio, USA). Ribonuclease A digestion was carried out at $37^{\circ} \mathrm{C}$ for 30 minutes. Protected fragments were separated on a $6 \%$ polyacrylamide/7 $\mathrm{M}$ urea gel, followed by autoradiography.

In situ bybridization. In situ hybridization was performed as described previously (14). A COX2 fragment was generated from the $3^{\prime}$ untranslated region of rabbit COX 2 cDNA using PCR. A 692-bp product was cloned into pCRII (Invitrogen) and sequenced to determine orientation. Sense and antisense riboprobes were transcribed in the presence of $[\alpha-$ ${ }^{35}$ S]UTP. Kidneys were fixed in $4 \%$ paraformaldehyde and then embedded in paraffin. Sections $(7 \mathrm{~mm})$ were cut and hybridized at $50-55^{\circ} \mathrm{C}$ for approximately 18 hours. After hybridization, sections were washed at $50^{\circ} \mathrm{C}$ in $50 \%$ formamide, $2 \times \mathrm{SSC}$, and 100 $\mathrm{mM} \beta$-mercaptoethanol for 60 minutes, treated with RNase A $\left(10 \mu \mathrm{g} / \mathrm{ml}, 37^{\circ} \mathrm{C}, 30\right.$ minutes $)$, followed by washes in $19 \mathrm{mM}$ Tris, $5 \mathrm{mM}$ EDTA, $500 \mathrm{mM} \mathrm{NaCl}$ $\left(37^{\circ} \mathrm{C}\right), 2 \times \operatorname{SSC}\left(50^{\circ} \mathrm{C}\right)$, and $0.1 \times \operatorname{SSC}\left(50^{\circ} \mathrm{C}\right)$. Slides were dehydrated with ethanol containing $300 \mathrm{mM}$ ammonium acetate. Photomicrographs were taken from slides dipped in $\mathrm{K} 5$ emulsion (Ilford Ltd., Knutsford, Cheshire, United Kingdom) diluted 1:1 with $2 \%$ glycerol/water and exposed for 7 days at $4^{\circ} \mathrm{C}$. After development in Kodak D-19, slides were counterstained with hematoxylin. Photomicrographs were taken with a Zeiss Axioskop microscope using bright-field optics.

$A d-I \kappa B m u t, A d-C O X 2 / A S, A d-I K K \alpha$, and Ad-GL. Adenoviral vectors encoding a dominant-negative IKB and a constitutive-active IKB kinase $\alpha$ (IKK $\alpha$ ) or an antisense COX2 were used to modulate NF- $\mathrm{KB}$ activity or to downregulate COX2, respectively, in cultured RMICs. The construction, purification, and amplification of the dominant-negative $I \kappa B \alpha$ adenovirus, COX2 antisense adenovirus, and green fluo-
Table 1

Urinary osmolality in animals with free access to $5 \%$ sugar water or water deprivation ( $\mathrm{mOsm} / \mathrm{kg} \mathrm{H}{ }_{2} \mathrm{O}$ )

$\begin{array}{llll} & \text { 5\% sugar water }(n) & \text { Water deprivation }(n) & P \text { value } \\ \text { Rabbits }^{\mathrm{A}} & 655 \pm 107(4) & 3441 \pm 514(3) & <0.01 \\ \text { Mice }^{\mathrm{B}} & 621 \pm 268(5) & 3018 \pm 334(5) & <0.01\end{array}$

ARabbits were deprived of water for 72 hours. ${ }^{B}$ Mice were deprived of water for 24 hours.

rescent protein (GFP) adenovirus were as described previously $(9,22)$. Briefly, the transdominant inhibitor of NF- $\kappa B$, avian IkB- $\alpha \mathrm{S} 36 / 40 \mathrm{~A}$, was constructed by oligonucleotide site-directed mutagenesis and subcloned into shuttle plasmid pACCMV (22, 23). For construction of a COX 2 antisense adenovirus (Ad-COX2/AS), a full-length rabbit COX2 cDNA fragment was subcloned into pACCMV in a orientation to produce a COX2 antisense transcript. Constitutively active IKK $\alpha$ (IKK1) cDNA was kindly provided by Frank Mercurio (Signal Pharmaceuticals, San Diego, California, USA) and subcloned into pAC-

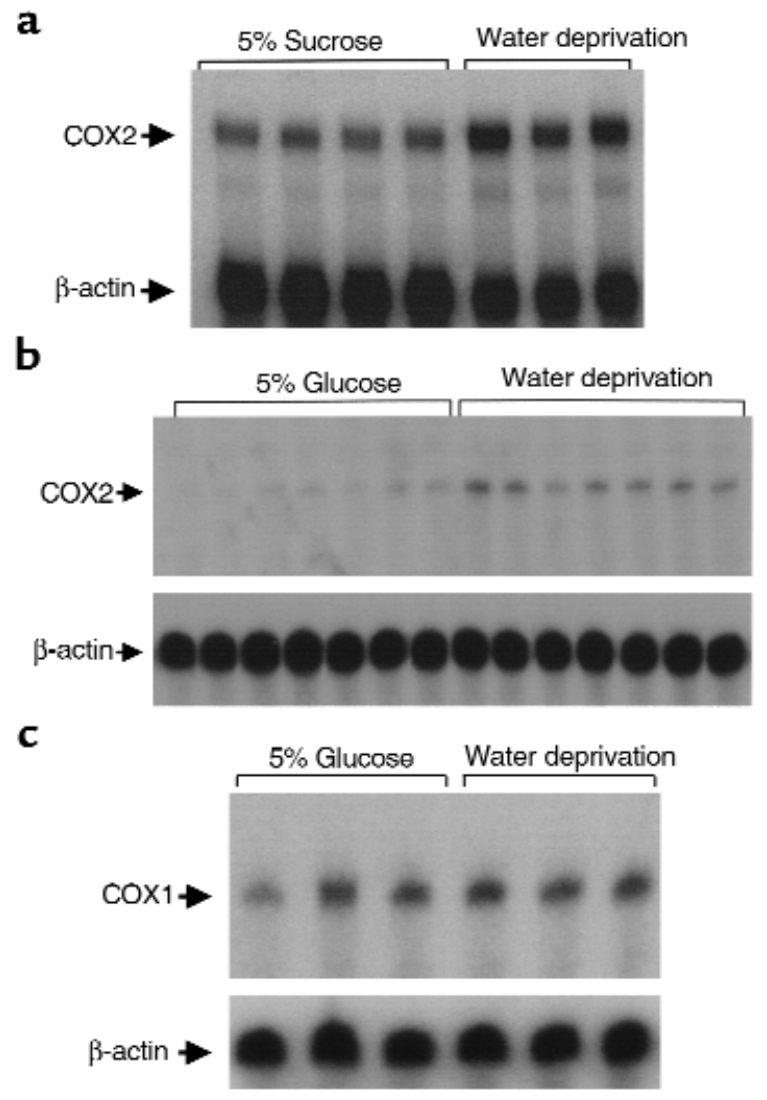

Figure 1

Effect of water deprivation on renal medullary COX2 mRNA expression. (a) Rabbit renal medullary COX2 mRNA expression was detected with nuclease protection using rabbit COX2 and $\beta$-actin riboprobes on extracts from renal medulla after a 72-hour water deprivation or free access to $5 \%$ sucrose water. (b) Mouse kidney COX 2 mRNA expression after 24 hours of water deprivation, determined by nuclease protection assay. (c) Nuclease protection assay showing mouse renal COX1 mRNA expression after 24 hours of water deprivation. 


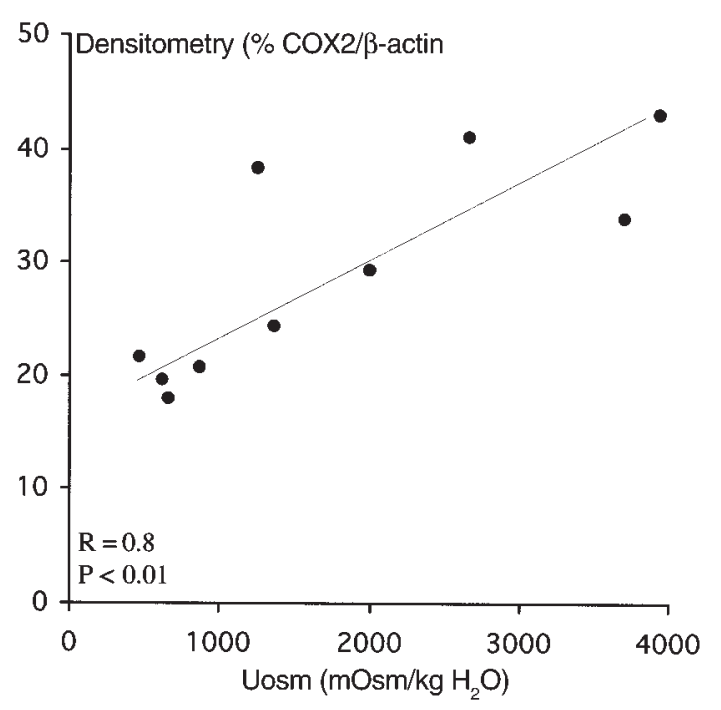

Figure 2

Correlation between renal medullary COX2 mRNA expression and urinary osmolality after water deprivation or free access to $5 \%$ sucrose water.

CMV for IKK $\alpha$ adenovirus construction. The IKK $\alpha$ was constitutively activated by introducing Ser-Glu mutations at Ser176 and Ser180 residues (24). An adenovirus expressing green fluorescent protein was constructed as an adenovirus control. A full-length green fluorescent protein cDNA (Green Lantern [GL]; GIBCO Life Technologies, Gaithersburg, Maryland, USA) was subcloned into the KpnI/XbalI sites of pACCMV, yielding the sense GL construct. The pACCMV shuttle plasmid contains the cytomegalovirus (CMV) immediate early enhancer and promoter and the SV40 polyadenylation sequence (25). The resulting shuttle plasmids containing dominant-negative $\mathrm{IkB}, \mathrm{GL}$, or antisense COX2 inserts were cotransfected into HEK 293 cells along with the pJM17 vector by standard calcium phosphate coprecipitation methods (25). Ad-IkBmut, Ad-COX2/AS, Ad-IKK $\alpha$, and Ad-GL were generated by a homologous recombination event, resulting in plaque formation in the HEK293 cells. The resulting infectious adenovirus was plaque purified. For infection of RMICs, $200 \mu \mathrm{l}$ of virus (moi: 100) was added to each culture dish. After a 2-hour incubation, the virus was removed, and fresh DMEM with 10\% FBS was added. Experiments were carried out 48-72 hours after infection.

Electrophoretic mobility-shift assay. Electrophoretic mobility-shift assay (EMSA) was carried out using a commercial NF- $\kappa B$ Gel Shift Assay Kit (Stratagene, La Jolla, California, USA). The NF- $\mathrm{kB}$ oligonucleotide probe was end labeled with $\gamma^{32} \mathrm{P}$. Binding of the probe $(20,000 \mathrm{cpm})$ to the nuclear extracts $(5 \mu \mathrm{g})$ was performed in a $25-\mu \mathrm{l}$ incubation buffer for 20 minutes at room temperature. For supershift, antiRel Ab's (Santa Cruz Biotechnology Inc.) were incubated with nuclear extracts for 30 minutes before labeled NF- $\mathrm{KB}$ oligonucleotide probe was added. The reaction mixture was then applied to $16 \times 20 \mathrm{~cm}^{2} 5 \%$ polyacrylamide gel and run at $200 \mathrm{~V}$ for 3 hours, followed by autoradiography.

Cell viability analysis. Cell viability was assessed using crystal violet $(26,27)$. After treatment with NSAIDs or hypertonicity for predetermined time periods, culture medium was removed and plates were washed with PBS. The remaining viable attached cells were stained with $0.5 \%$ crystal violet in $50 \%$ methanol for 15 minutes. The plates were then gently rinsed with water and dried. A solution containing $0.1 \mathrm{M}$ citrate sodium, $\mathrm{pH} 5.4$, and $20 \%$ methanol was added, and 30 minutes later, the absorbance at $570 \mathrm{~nm}$ was read using a spectrophotometer. The percentage of cell survival was defined as the relative absorbance of treated versus untreated cells. The unattached cells in the medium were confirmed to be dead by trypan blue-exclusion assay.

\section{Results}

Effect of water deprivation on renal medullary COX2 expression. Water deprivation significantly increased urinary osmolality when compared with urine obtained from rabbits or mice allowed free access to $5 \%$ sugar water (Table 1). Kidneys from water-deprived rabbits and mice exhibited increased COX2 mRNA expression determined by nuclease protection (Figure 1). COX1 expression was not significantly altered in the same assay (Figure 1). Densitometry revealed water deprivation increased COX2 mRNA expression fivefold in

\section{Figure 3}

In situ hybridization of COX2 in rabbit kidney after water deprivation. (a) Autoradiograph showing the distribution of COX2 mRNA in the kidney from free wateraccessed rabbit or water-deprived rabbit. (b) Photomicrograph of in situ hybridization for COX2 in papilla after water deprivation. Black grains represent hybridized COX2 mRNA.

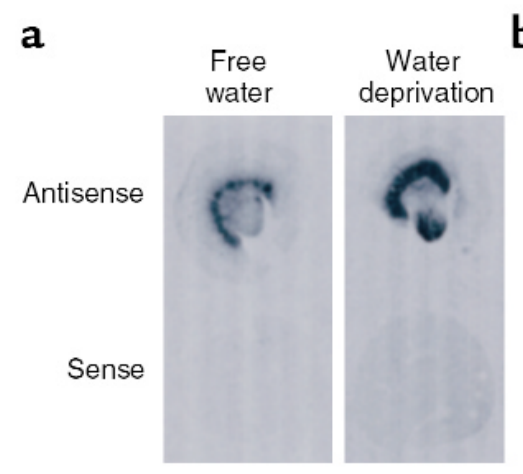

b

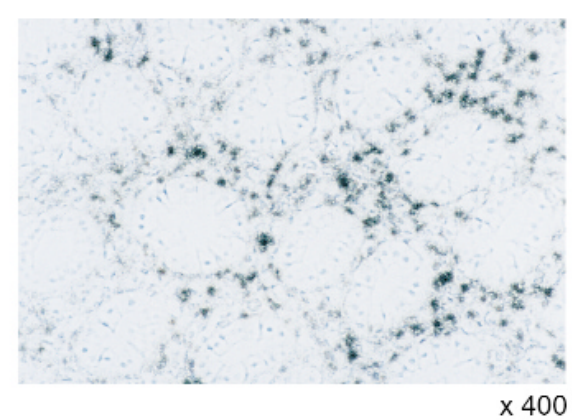




\section{Figure 4}

Immunoblot of COX2 and COX 1 on protein extracts from cultured rabbit RMICs exposed to hyperosmotic conditions. Confluent RMICs were incubated in different osmotic media for up to 12 hours. Cellular proteins $(30 \mu \mathrm{g})$ were subjected to SDS-PAGE and immunoblotted with anti-COX2 or anti-COX1 Ab's. (a) Time course of COX2 expression when RMICs were cultured in hypertonic media (500 mOsm produced by $\mathrm{NaCl}$ ). (b) Effect of hyperosmolality produced by different osmoles ( $\mathrm{NaCl}$, mannitol, or urea) on COX2 and COX1 expression. Representative data from two experiments.

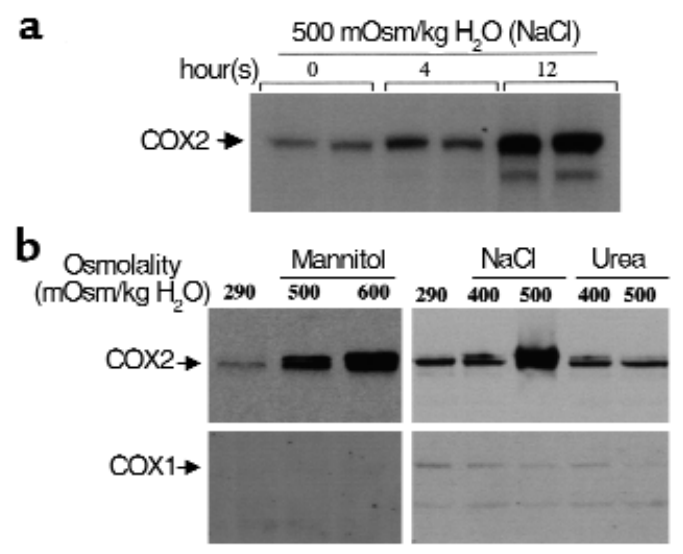

mice (COX2/ $\beta$-actin: $0.21 \pm 0.05$ vs. $0.04 \pm 0.02 ; P<$ $0.01)$ and twofold in rabbits (COX2/ $\beta$-actin: $0.39 \pm$ 0.03 vs. $0.20 \pm 0.02 ; P<0.05$ ) (see Figure 1 ). COX2 mRNA expression in the renal medulla correlated significantly with urinary osmolality $(r=0.8, P<0.01)$ (Figure 2). In situ hybridization showed COX2 mRNA in the renal medulla strictly localized over the interstitium, including interstitial cells in both control and water-deprived rabbits. COX2 mRNA was not detected over collecting ducts (Figure 3). Water deprivation did not change renal COX1 mRNA expression in mice (Figure 1).

Hypertonicity directly induces COX2 expression in RMICs. To examine whether increased tonicity directly induces COX2 in RMICs, immunoblots were performed on protein extracts from cultured RMICs. Exposing cultured RMICs to hypertonic conditions achieved using either $\mathrm{NaCl}$ or mannitol directly induced COX2, but not COX1, expression (Figure 4). Hypertonicity induced COX2 immunoreactivity as early as 4 hours after exposure to hypertonic media, and COX2 increased further at 12 hours (Figure 4). In contrast, hyperosmolality produced by the membrane-permeable osmole urea did not increase COX2 expression (Figure 4). Exposure of RMICs to hypertonic media also significantly increased COX2 mRNA expression (see Figure 7). Shifting RMICs to hypertonic media also increased PGE2 production sevenfold over that measured in isotonic media (48.6 $\pm 0.8 \mathrm{ng} / \mathrm{ng}$ protein $/ \mathrm{h}$ vs. $7.0 \pm 0.5 \mathrm{ng} / \mathrm{ng}$ protein $/ \mathrm{h}, P$ $<0.01)$, consistent with functional activation of COX2 by hypertonicity.

Water deprivation and bypertonicity increase in vivo and in vitro $N F-\kappa B$ activity. Since, in some cells, COX2

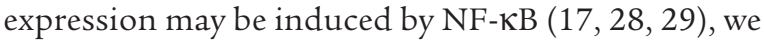
examined whether renal NF- $\mathrm{KB}$-mediated transcription was also activated by water deprivation. Mice transgenic for a NF- $\kappa$ B response element (HIV LTR) fused with a reporter luciferase gene (transgenic line HLL) were subjected to water deprivation, and renal luciferase activity was determined. Water deprivation increased renal luciferase activity more than 300\% above that in mice provided $5 \%$ glucose water, from
$134 \pm 17 \mathrm{U} / \mu \mathrm{g}$ protein $(n=8)$ to $401 \pm 72 \mathrm{U} / \mu \mathrm{g}$ protein $(n=8)(P<0.05$, Figure 5$)$, supporting in vivo activation of NF- $\kappa \mathrm{B}$. Hypertonicity also directly induced $\mathrm{NF}-\kappa \mathrm{B}-$ driven luciferase expression in cultured HLL RMICs by $250 \%$ over that in isotonic media (from $84.8 \pm 23 \mathrm{U} / \mu \mathrm{g}$ protein to $213.8 \pm 26$ $\mathrm{U} / \mu \mathrm{g}$ protein; $P<0.01$ ) (Figure 5 ).

Hypertonicity increased binding of proteins from RMIC nuclear extracts to a radio-labeled NF- $\kappa B$ oligonucleotide derived either from the promoter region of IgG light chain (Figure 6) or from the human COX2 gene promoter (data not shown). Excess unlabeled NF-KB oligonucleotide completely eliminated the

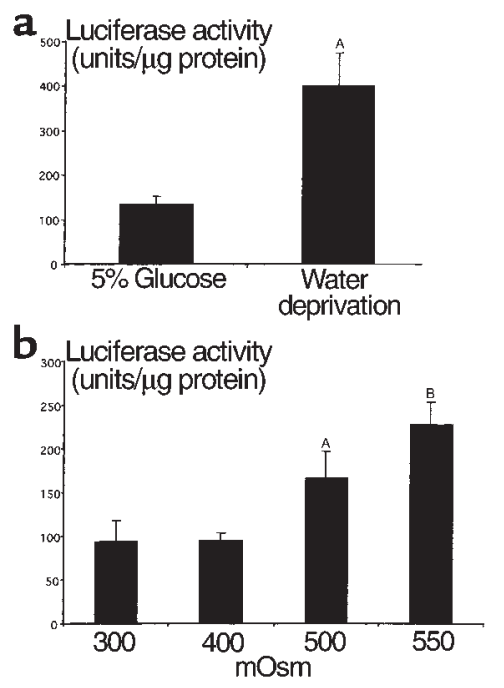

\section{Figure 5}

Effect of water deprivation on kidney NF-KB activity from HLL mice. (a) Transgenic mice with luciferase reporter gene driven by a NF-KB response element HIV LTR sequence were water deprived $(n=8)$ or allowed free access to $5 \%$ glucose water $(n=8)$ for 24 hours. The kidney luciferase activity was determined as in Methods and adjusted for the amount of protein. ${ }^{A} P<0.05$. (b) Effect of hypertonicity on NF- $\kappa B$ activity in RMICs cultured from HLL mice. Cultured HLL-mouse RMICs were exposed to media with different tonicity (from isotonic to $550 \mathrm{mOsm}$ produced by $\mathrm{NaCl}$ ) for 20 hours. Luciferase activity was determined and adjusted for the amount of protein. ${ }^{A} P<0.05 ;{ }^{B} P<0.01$. 


\section{Figure 6}

Effect of hypertonicity on binding activity of NF- $\kappa B$ in cultured RMICs. (a) EMSA using ${ }^{32} \mathrm{P}$-labeled NF- $\mathrm{KB}$ response sequence as a probe. RMICs were exposed to isotonic medium (second lane) or hypertonic medium (third lane), or pretransduced with dominantnegative IKB adenovirus (Ad-IKBmut) and then exposed to hypertonic conditions (fourth lane). Nuclear proteins ( $5 \mu \mathrm{g}$ ) were incubated with ${ }^{32} \mathrm{P}$-labeled NF- $\mathrm{KB}$ oligonucleotide and subjected to $5 \%$ acrylamide gel. (b) Supershift of EMSA by preincubating nuclear extracts from RMICs exposed to hypertonicity with Ab's against NF$\kappa B$ subunits. Arrows indicate supershifted (SS) DNA probe/protein complexes. Representative data from three experiments are shown.

protein binding to the labeled probe. The identity of protein(s) bound to the NF- $\mathrm{KB}$ probe was further characterized using a supershift assay with Ab's against five known NF- $\kappa \mathrm{B}$ family subunits. Ab's to p50 and p65 caused a shift of the binding complex, whereas Ab's to c-Rel, Rel B, and p52 had no effect, suggesting that p50 and p65 were the main components in interstitial cells activated by hypertonicity.

Blocking NF- $\kappa B$ activation reduces bypertonic induction of interstitial cell COX2. The role of NF- $\mathrm{\kappa B}$ in the hypertonic induction of COX2 was examined by blocking NF- $\kappa B$ activation with a dominant-negative I $\kappa B$ adenovirus (Ad-IKBmut). Successful transduction of dominant-negative IKB into cultured RMICs was confirmed with an immunoblot using a specific $\mathrm{Ab}$ against dominant-negative IKB (data not shown). Not only did Ad-IKBmut abolish binding of nuclear factors to a NF- $\mathrm{KB}$ oligonucleotide on gel shift (Figure 6), it also significantly reduced hypertonicityinduced COX2 protein expression by $64.5 \pm 4.4 \%(n=$ 3) compared with Ad-GL (Figure 7). COX2 mRNA expression was also reduced by blocking activation of NF- $\kappa \mathrm{B}$ using the dominant-negative I $\kappa \mathrm{B}$ (Figure $7 \mathrm{~b}$ ).

$N F-\kappa B$ activation drives COX2 expression in medullary interstitial cells. RMIC NF- $\mathrm{\kappa B}$ was activated by transduc-

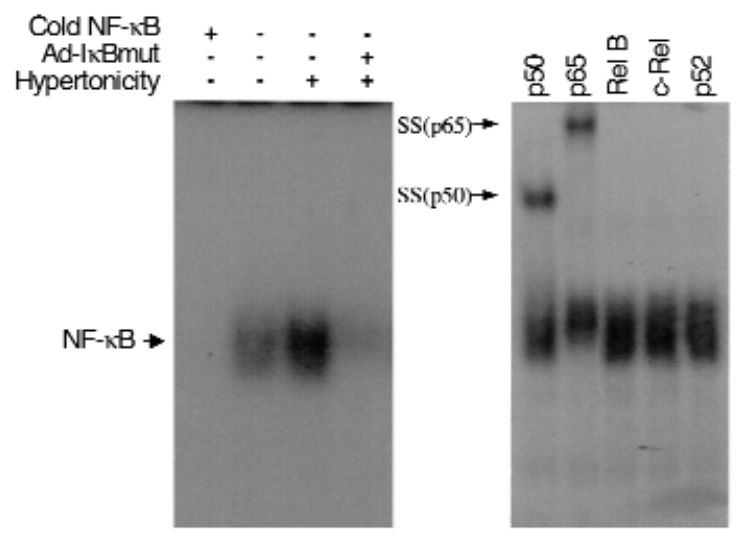

tion with a constitutively active IKK $\alpha$ adenoviral vector (Ad-IKK $\alpha$ ). IKK phosphorylates IKB, leading to its degradation and subsequent activation of NF- $\mathrm{KB}(30$, 31). Transduction of IKK $\alpha$ into cultured RMICs from HLL mice increased NF-KB-driven luciferase activity eightfold (from $63.7 \pm 2.7 \mathrm{U} / \mu \mathrm{l}$ to $513.1 \pm 25.6 \mathrm{U} / \mu \mathrm{l}, n$ $=3, P<0.01)$. Overexpression of the constitutively active IKK $\alpha$ in RMICs also increased COX2 immunoreactive protein expression as well as COX2 mRNA expression, an effect that was abolished by cotransducing the dominant-negative IKB, which lacks the IKK phosphorylation sites (Figure 8).

COX2 inbibition decreases medullary interstitial cell survival following hypertonic stress. Typically more than $90 \%$ of cultured RMICs survive a tonicity shift from 300 to $500 \mathrm{mOsm}$. Since this change in tonicity is accompanied by increased COX2 expression, we examined the effect of a COX2-selective inhibitor SC58236 $(0-5 \mu \mathrm{M})$ on RMIC viability. In isotonic conditions, $0.5-5 \mu \mathrm{M}$ SC58236 did not significantly affect RMIC viability, however, following the shift to hypertonic conditions, $0.5-1 \mu \mathrm{M}$ SC58236 decreased cell viability by $50 \pm 6 \%$. Viability further decreased by $77 \pm 13 \%$ using $5 \mu \mathrm{M} \mathrm{SC58236}$ (Figure 9), suggesting a role for COX2 in RMIC survival. These findings

\section{Figure 7}

Effect of dominant-negative $1 \kappa B \alpha$ on hypertonicity induced COX2 protein and mRNA expression in cultured RMICs. RMICs were transduced with dominant Ad-IKBmut or Ad-GL. Two days later, cells were exposed to isotonic (iso; $300 \mathrm{mOsm} / \mathrm{kg} \mathrm{H}_{2} \mathrm{O}$ ) or hypertonic (hyper; $550 \mathrm{mOsm} / \mathrm{kg} \mathrm{H}_{2} \mathrm{O}$, produced by $\mathrm{NaCl}$ ) media for 12 hours. (a) Cellular protein was extracted and subjected to SDS-PAGE $(30 \mu \mathrm{g})$ and probed with anti-COX2 Ab. (b) Total RNA was isolated, and $5 \mu \mathrm{g}$ of total RNA was used for nuclease protection assay using radio-labeled COX2 and $\beta$-actin probe. Representative data from three experiments.

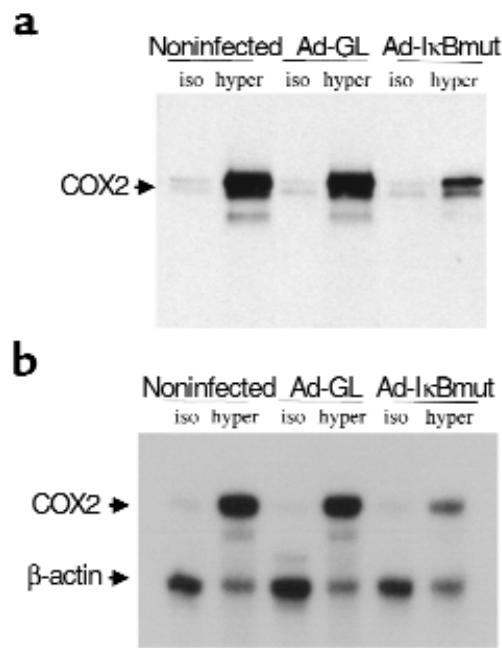


were confirmed by downregulating COX2 using an antisense adenovirus (Ad-COX2/AS). Significant suppression of hypertonic induction of COX2 by the AdCOX2/AS was demonstrated with an immunoblot (Figure 10). A control adenovirus expressing GL did not affect COX2, either at baseline or after hypertonic stress. When cultured RMICs were transduced with either Ad-GL or Ad-COX2/AS and exposed to hypertonic media, RMIC viability was significantly reduced to $54 \pm 2.2 \%$ in the Ad-COX2/AS group as compared with $96 \pm 7.7 \%$ in Ad-GFP $(P<0.01$; Figure 10$)$. Furthermore, RMIC viability was significantly less in 500 mOsm versus isotonic conditions after Ad-COX2/AS transduction. These results suggest an important role for COX2 in promoting tolerance of hypertonic stress in RMICs (Figure 10).

COX2 inbibition induces apoptosis in RMICs after water deprivation. In four out of four rabbits treated with a COX2 inhibitor (SC58236), water deprivation was associated with the presence of apoptotic patches of RMICs. In contrast, no apoptosis was detected in renal papilla from rabbits treated with water deprivation alone or COX2 inhibitor alone (Figure 11).

\section{Discussion}

The medulla is the predominant site of renal prostanoid synthesis (32). Medullary PGs play an important role in maintaining normal renal function, including modulation of renal medullary blood supply and epithelial ion or water transport, particularly after dehydration, when renal PG production increases (33). The present study shows COX2, a ratelimiting enzyme in PG synthesis, increases in the renal medulla of both mice and rabbits after water deprivation or hypertonic stress. This is consistent with earlier reports in rats $(11,12)$. The present study only detected increased COX2 expression after water deprivation in the medullary interstitium. This increase in RMIC COX2 expression suggests a special role for prostanoids produced by these cells in the renal response to water deprivation.

Hypertonic media directly induced COX2 expression in cultured RMICs, suggesting that renal medullary tonicity is an important stimulus for COX2 expression. In contrast, hyperosmolality achieved by the cell-permeable solute urea did not increase COX2 expression in cultured RMICs. This finding contrasts with studies using the MIMCD collecting duct cell line (12), where urea alone increased COX2 expression. This may reflect important cellspecific differences in regulation of COX2 expression between these cell types. Whether these differences also exist in vivo is uncertain; however, the present studies failed to detect induction of COX2 in collecting ducts in either rabbits or mice, suggesting important cell-specific differences in COX2 regulation may also exist in vivo.

The present studies also examined the mechanism by which hypertonicity regulates COX2 gene expres- sion in RMICs. The $5^{\prime}$ flanking region of the COX2 gene possesses consensus sequences for several transcription factors, including CRE, NF- $\kappa B$, and NF-IL6 (34). These signaling mechanisms display variable efficacy in regulating COX2 expression, depending upon the cell type (35-37). The present study suggests that NF- $\kappa \mathrm{B}$ plays an important role in RMIC COX2 expression after hypertonic stress. Studies using the transgenic HLL NF- $\mathrm{KB}$ reporter mouse demonstrate in vivo activation of NF- $\kappa B$ in the kid-

\section{a}

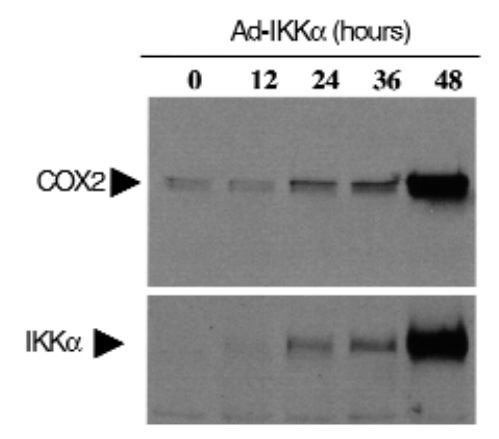

b

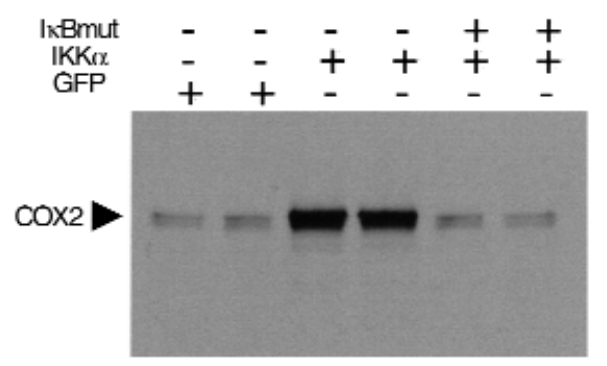

$\mathbf{C}$

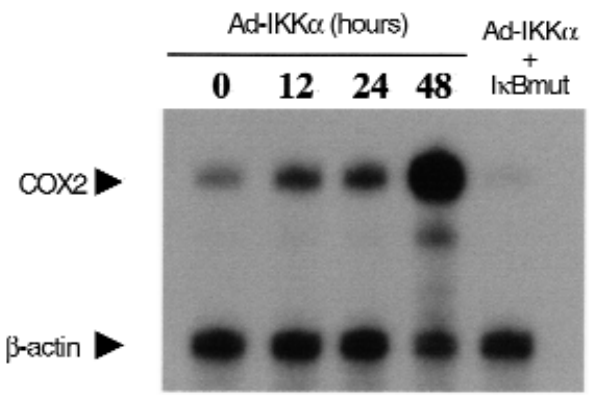

\section{Figure 8}

Effect of activation of NF- $\mathrm{KB}$ on COX2 expression. A constitutive active IKK $\alpha$ was transduced into cultured rabbit RMICs by an adenoviral vector, COX2 immunoreactive protein and COX 2 mRNA expressions were examined. (a) Immunoblot of COX2 before and 12, 24, 36 , and 48 hours after transduction of IKK $\alpha$. Successful IKK $\alpha$ transducing was examined by immunoblot using anti-IKK $\alpha A b$ (lower panel). (b) Dominant-negative IKB was transduced into RMICs together with constitutive active IKK $\alpha$, and their effect on COX2 expression was determined 48 hours later with immunoblot. (c) Nuclease protection assay showing COX2 mRNA expression in cultured RMICs transduced with the IKK $\alpha$ or IKK $\alpha$ together with IKBmut. 


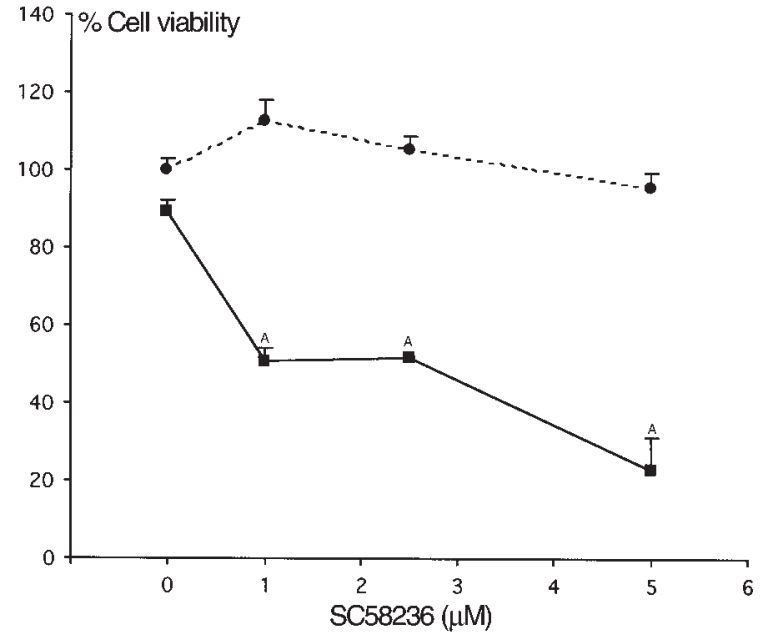

Figure 9

Effect of COX2-selective inhibitor SC58236 on survival of cultured RMICs challenged with hypertonic medium. RMICs were pretreated with COX2-selective inhibitor SC58236 (0-5 $\mu \mathrm{M})$ and exposed to isotonic (filled circles) and hypertonic media (filled squares; $500 \mathrm{mOsm}$ produced by $\mathrm{NaCl}$ ) for 12 hours. Cell viability was determined as described in Methods. ${ }^{A} P<0.01$ vs. cells under isotonic conditions in the presence of the same concentration of SC58236.

ney after water deprivation. Transcriptional activation of this NF- $\kappa B$ reporter was also directly induced by hypertonicity in cultured HLL mouse RMICs. Parallel supporting findings were obtained in cultured rabbit RMICs where supershift EMSAs suggest that p50 and p65 are the main components of the NF- $\kappa B$ family activated by hypertonicity. Normally, NF- $\kappa B$ proteins, including $\mathrm{p} 65$, c-REL, RELB, p105/p50, and $\mathrm{p} 100 / \mathrm{p} 52$, are sequestered in the cytoplasm of unstimulated cells as inactive homo- or heterodimers by a group of inhibitory proteins - IKBs $(31,38)$. Phosphorylation of $I \kappa B \alpha$ at ser $32 /$ ser36 by IKK is a key regulatory step in NF- $\mathrm{\kappa B}$ activation, leading to disassociation of I $\mathrm{KB}$ from NF- $\kappa \mathrm{B}$, allowing translocation of NF- $\kappa B$ into the nucleus and binding to DNA (30). In the present study, increased COX2 expression in RMICs was also achieved by expression of a constitutively active IKK, demonstrating activation of the native COX2 gene by NF$\kappa \mathrm{B}$ pathway. Furthermore, blocking NF- $\kappa \mathrm{B}$ activation with a dominant-negative $I \kappa B$ mutant adenovirus not only blocked IKK-induced COX2 expression, but also reduced hypertonic induction of COX2 mRNA and protein. These findings directly link NF- $\kappa \mathrm{B}$ activation to hypertonic induction of COX2 expression in RMICs.

The events by which hypertonicity activates NF- $\kappa \mathrm{B}$ remain unclear. It has been shown that osmotic stress can induce clustering of several cytokine receptors, including TNF- $\alpha$ receptor (39), leading to activation of TNFR-associated factor 2 (TRAF2). This protein then activates IKK through an unknown mechanism $(40,41)$. Recently, IKK has been shown to be phosphorylated and activated by a group of MAPK kinase kinases (MAP3K) (30). The MAP kinase pathway is the mammalian counterpart of the osmoregulated HOG-1 system in yeast (4), which has also been shown to be activated by dehydration (3). Thus, activation of NF- $\mathrm{KB}$ and MAP kinase pathways by hypertonicity may be initiated by the same stimulus. MAP kinase activation by cytokines also upregulates COX2 expression by mechanisms independent of NF- $\mathrm{KB}(15,16,42,43)$. This latter effect may account for the residual induction of COX2 by hypertonicity after blocking NF- $\kappa B$ activity (Figure 7).

The present findings reveal a role for COX2 in facilitating the ability of RMICs to survive hyperosmotic stress. After COX2 inhibition using submicromolar concentrations of SC58236, RMIC survival was markedly reduced. This effect was only observed after shifting the cells to hypertonic conditions. In

a

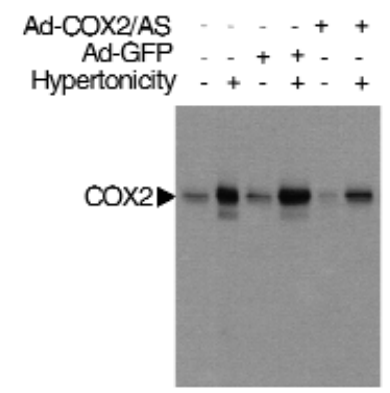

b

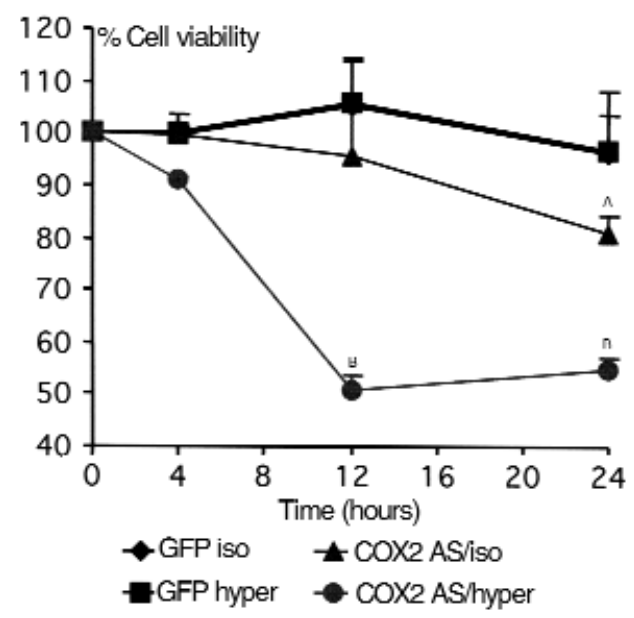

Figure 10

Effect of COX2 downregulation on survival of RMICs cultured in hypertonic medium. (a) Downregulation of COX2 by an adenovirus encoding COX2 antisense (Ad-COX2/AS) in RMICs. Representative immunoblot of COX2 on protein extracts from cultured RMICs transduced with Ad-COX2/AS or green fluorescent protein adenovirus (Ad-GFP), and exposed to isotonic or hypertonic (produced by $\mathrm{NaCl}$ ) media. (b) Cultured RMICs were transduced with AdCOX2/AS or Ad-GFP, and cultured in hypertonic medium. Cell viability was determined 4,12 and 24 hours after exposure to hypertonic medium, as described in Methods. ${ }^{A} P<0.05 ;{ }^{B} P<0.01$ compared with GFP isotonic. 

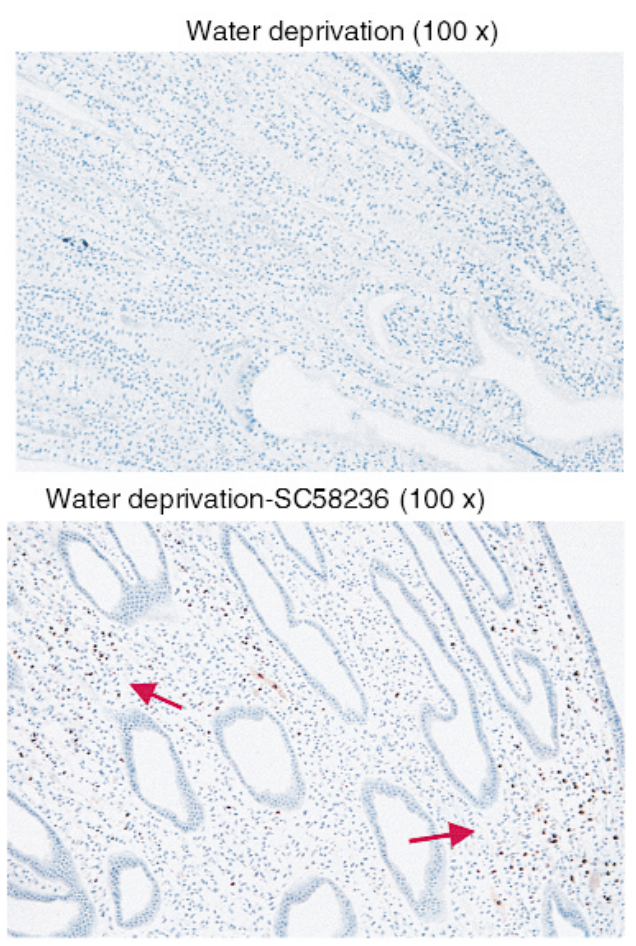

Water deprivation-SC58236 (400 x)

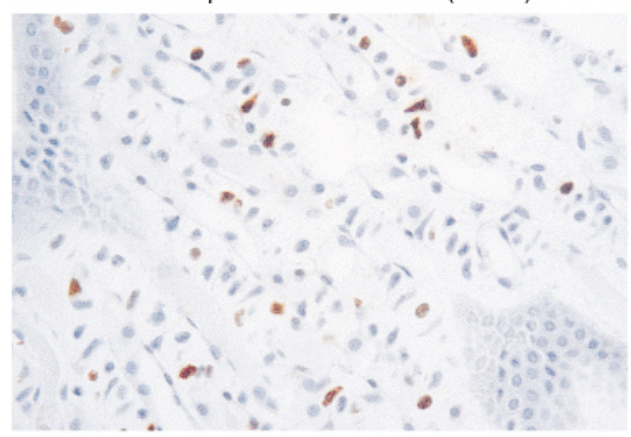

\section{Figure 11}

Apoptosis of medullary interstitial cells after COX2 inhibition in water-deprived rabbits. Rabbits were treated with vehicle (top) or COX2 inhibitor SC58236 (middle and bottom) for 10 days, followed by water deprivation as in Methods. Apoptotic changes were assessed by TUNEL assay and were identified by the brown peroxidase reactions. The arrows indicate patches of apoptotic cells.

contrast, these concentrations of SC58236 had no effect on cell survival in isotonic conditions. These doses of the COX2 inhibitor SC58236 are 20- to 50fold lower than those that were found previously to kill cells under isotonic conditions $(9,44,45)$. The conclusion that cell death is due to COX2 inhibition is further supported by studies downregulating COX2 using an antisense adenovirus. Hypertonicity also significantly enhanced the lethality of antisense COX2 downregulation in RMICs. Importantly, in vivo studies also suggest RMICs' viability depends on COX2 function, particularly after dehydration. Patches of apoptotic COX2 expressing RMICs were only observed in water-deprived rabbits after treat- ment with selective COX2 inhibitor. The localization of cell death to COX2 expressing RMICs in vivo reinforces the link between COX2 function and survival of these cells.

Increased PGE2 production after hypertonicity may reflect increased phospholipase $\mathrm{A}_{2}$-mediated arachidonate release $(46,47)$. The downstream products of COX2-mediated arachidonic acid metabolism (e.g., PGs) could be an important factor promoting RMIC survival after hypertonic stress. Alternatively, it is possible that COX inhibition may decrease cellular tolerance of hypertonicity by elevating levels of free arachidonic acid and/or shunting its metabolism to other pathways, such as leukotrienes or cytochrome P450 metabolites $(48,49)$.

Long-term use of COX-inhibiting NSAIDs has been associated with papillary necrosis and progressive renal structural and functional deterioration $(10,50)$. NSAID-induced renal damage is more likely to occur in the setting of dehydration, suggesting a critical dependence of renal function upon COX metabolism in this setting (51). Increased COX2 expression after dehydration is consistent with this finding. Interestingly, in the present experiments only patches of apoptotic RMICs were seen after COX2 inhibition and water deprivation, and papillary necrosis was not detected. This result, which is consistent with an earlier report that RMICs are an early target of injury in analgesic nephropathy (52), also suggests that repeated injury of these cells is an early event in analgesic nephropathy. Other roles for RMIC COX2-derived prostanoids may relate to maintenance of medullary blood flow. RMICs are in direct contact with vasa recta (53), so these cells or the products of COX2 from these cells may dilate and increase flow through these vessels $(54,55)$. Taken together, increased COX2 expression could play an important role in maintaining viability and blood supply of the renal medulla.

In summary, these studies demonstrate that water deprivation and hypertonicity activate NF- $\mathrm{KB}$ both in vivo and in vitro. NF- $\mathrm{KB}$ induces COX2 expression in RMICs, and increased COX2 expression is critical for the ability of RMICs to survive hypertonic stress. This suggests an important role for COX2 as a survival factor in the renal medulla.

\section{Acknowledgments}

M.D. Breyer is the recipient of a Veterans Administration Career Development award. This study was supported by National Institute of Diabetes and Digestive and Kidney Diseases (NIDDK) grant 1P50-DK-39261, George M. O'Brien Kidney Center (M.D. Breyer), NIDDK grant DK-37097, and funding from Searle/Monsanto Pharmaceuticals (M.D. Breyer). The constitutively active IKK1 cDNA was a generous gift from F. Mercurio. The authors thank P. Isakson and K Siebert (Searle/Monsanto Pharmaceuticals) for providing SC58236. The authors thank 
R. Reyadh for preparing RMICs and A. Venkatakrishnan for making Ad-IKK $\alpha$.

1. Burg, M., Kwon, E., and Kultz, D. 1997. Regulation of gene expression by hypertonicity. Annu. Rev. Physiol. 59:437-455.

2. Handler, J.S., and Kwon, H.M. 1997. Kidney cell survival in high tonicity. Comp. Biochem. Physiol. A Physiol. 117:301-306.

3. Wojtaszek, P.A., Heasley, L.E., and Berl, T. 1998. In vivo regulation of MAP kinases in Ratus norvegicus renal papilla by water loading and restriction. $J$. Clin. Invest. 102:1874-1881.

4. Sprague, G.F., Jr. 1998. Control of MAP kinase signaling specificity or how not to go HOG wild. Genes Dev. 12:2817-2820.

5. Ferraris, J.D., et al. 1996. ORE, a eukaryotic minimal essential osmotic response element. The aldose reductase gene in hyperosmotic stress. J. Biol. Chem. 271:18318-18321.

6. Nadkarni, V., Gabbay, K.H., Bohren, K.M., and Sheikh-Hamad, D. 1999. Osmotic response element enhancer activity. Regulation through p38 kinase and mitogen-activated extracellular signal-regulated kinase kinase. J. Biol. Chem. 274:20185-20190.

7. Rim, J.S., et al. 1998. Transcription of the sodium/myo-inositol cotransporter gene is regulated by multiple tonicity-responsive enhancers spread over 50 kilobase pairs in the 5 'flanking region. J. Biol. Chem. 273:20615-20621.

8. Miyakawa, H., et al. 1998. Cis- and trans-acting factors regulating transcription of the BGT1 gene in response to hypertonicity. Am. J. Physiol. 274:F753-F761.

9. Hao, C., Kömhoff, M., Guan, Y., Redha, Y., and Breyer, D. 1999. Selective targeting of cyclooxygenase-2 reveals its role in renal medullary interstitial cell survival. Am. J. Physiol. 277:F352-F359.

10. Murray, M.D., and Brater, D.C. 1993. Renal toxicity of the non-steroidal anti-inflammatory drugs. Annu. Rev. Pharmacol. Toxicol. 32:435-465.

11. Cowley, B.D., Jr., Muessel, M.J., Douglass, D., and Wilkins, W. 1995. In vivo and in vitro osmotic regulation of HSP-70 and prostaglandin synthase gene expression in kidney cells. Am. J. Physiol. 269:F854-F862.

12. Yang, T., Schnermann, J.B., and Briggs, J.P. 1999. Regulation of cyclooxygenase-2 expression in renal medulla by tonicity in vivo and in vitro. Am. J. Physiol. 277:F1-F9.

13. Harris, R, et al. 1994. Cyclooxygenase-2 is associated with the macula densa of rat kidney and increases with salt restriction. J. Clin. Invest. 94:2504-2510.

14. Guan, Y., et al. 1997. Cloning, expression, and regulation of rabbit cyclooxygenase-2 in renal medullary interstitial cells. Am. J. Physiol. 273:F18-F26.

15. Scherle, P.A., et al. 1998. Inhibition of MAP kinase kinase prevents cytokine and prostaglandin E2 production in lipopolysaccharide-stimulated monocytes. J. Immunol. 161:5681-5686.

16. Matsuura, H., et al. 1999. Regulation of cyclooxygenase-2 by interferon gamma and transforming growth factor alpha in normal human epidermal keratinocytes and squamous carcinoma cells. Role of mitogen-activated protein kinases. J. Biol. Chem. 274:29138-29148.

17. von Knethen, A., Callsen, D., and Brune, B. 1999. Superoxide attenuates macrophage apoptosis by NF-kappa B and AP-1 activation that promotes cyclooxygenase-2 expression. J. Immunol. 163:2858-2866.

18. Gavrieli, Y., Sherman, Y., and Ben-Sasson, S. 1992. Identification of programmed cell death in situ via specific labeling of nuclear DNA fragmentation. J. Cell Biol. 119:493-501.

19. Blackwell, T., et al. 2000. Multi-organ NF-kB activation in a transgenic mouse model of systemic inflammation. Am. J. Respir. Crit. Care Med. In press.

20. Burger-Kentischer, A., et al. 1999. Hypertonicity-induced accumulation of organic osmolytes in papillary interstitial cells. Kidney Int. 55:1417-1425.

21. Chomczynski, P., and Sacchi, N. 1987. Single-step method of RNA isolation by acid guanidinium thiocyanate-phenol chloroform extraction. Anal. Biochem. 162:126-159.

22. Oyama, T., et al. 1998. Vascular endothelial growth factor affects dendritic cell maturation through the inhibition of nuclear factor- $\mathrm{kB}$ activation in hemopoietic progenitor cells. J. Immunol. 160:1224-1232.

23. Sekhar, K., et al. 1997. Expression of glutathione and gamma-glutamylcysteine synthetase mRNA is jun dependent. Biochem. Biophys. Res. Commun. 234:588-593

24. Mercurio, F., et al. 1997. IKK-1 and IKK-2: cytokine-activated IKB kinases essential for NF-kB activation. Science. 278:860-866.

25. Becker, T., et al. 1994. Use of recombinant adenovirus for metabolic engineering of mammalian cells. Methods Cell Biol. 43:161-189.

26. Wang, C.Y., Mayo, M.W., and Baldwin, A.S., Jr. 1996. TNF- and cancer therapy-induced apoptosis: potentiation by inhibition of NF-kappaB. Science. 274:784-787

27. Mehlen, P., Kretz-Remy, C., Preville, X., and Arrigo, A.P. 1996. Human hsp27, Drosophila hsp27 and human alphaB-crystallin expression-mediated increase in glutathione is essential for the protective activity of these proteins against TNFalpha-induced cell death. EMBO J. 15:2695-2706.

28. Yamamoto, K., Arakawa, T., Ueda, N., and Yamamoto, S. 1995. Transcrip- tional roles of nuclear factor kappa B and nuclear factor-interleukin- 6 in the tumor necrosis factor alpha-dependent induction of cyclooxygenase-2 in MC3T3-E1 cells. J. Biol. Chem. 270:31315-31320.

29. Liu, S.F., Ye, X., and Malik, A.B. 1999. Inhibition of NF-kappaB activation by pyrrolidine dithiocarbamate prevents in vivo expression of proinflammatory genes. Circulation. 100:1330-1337.

30. Karin, M. 1999. How NF-kappaB is activated: the role of the IkappaB kinase (IKK) complex. Oncogene. 18:6867-6874.

31. Ghosh, S., May, M., and Kopp, E. 1998. NF-kB and Rel proteins: evolutionarily conserved mediators of immune response. Annu. Rev. Immunol. 16:225-260.

32. Larsson, C., and Anggard, E. 1973. Regional differences in the formation and metabolism of prostaglandins in rabbit kidney. Eur. J. Pharmacol. 21:30-36

33. Farese, R., Rodriguez-Colome, M., and O'Malley, B. 1980. Urinary prostaglandins following frusemide treatment and salt depletion in normal subjects and subjects with diabetic hyporeninaemic hypoaldosteronism. Clin. Endocrinol. (Oxf.). 13:447-453.

34. Xie, W., Merrill, J.R., Bradshaw, W.S., and Simmons, D.L. 1993. Structural determination and promoter analysis of the chicken mitogen-inducible prostaglandin $\mathrm{G} / \mathrm{H}$ synthase gene and genetic mapping of the murine homolog. Arch. Biochem. Biophys. 300:247-252.

35. Warnock, L., and Hunninghake, G. 1995. Multiple second messenger pathways regulate IL-1 beta-induced expression of PGHS- 2 mRNA in normal human skin fibroblasts. J. Biol. Chem. 163:172-178.

36. Newton, R., Kuitert, L.M., Bergmann, M., Adcock, I.M., and Barnes, P.J. 1997. Evidence for involvement of NF-kappaB in the transcriptional control of COX-2 gene expression by IL-1beta. Biochem. Biophys. Res. Commun. 237:28-32.

37. Chen, C.C., Chiu, K.T., Sun, Y.T., and Chen, W.C. 1999. Role of the cyclic AMP-protein kinase A pathway in lipopolysaccharide-induced nitric oxide synthase expression in RAW 264.7 macrophages. Involvement of cyclooxygenase-2. J. Biol. Chem. 274:31559-31564.

38. Gilmore, T., and Morin, P. 1993. The IkB proteins: members of a multifunctional family. Trends Genet. 9:427-433.

39. Rosette, C., and Karin, M. 1996. Ultraviolet light and osmotic stress: activation of the JNK cascade through multiple growth factor and cytokine receptors. Science. 274:1194-1197.

40. Orlinick, J., and Chao, M. 1998. TNF-related ligands and their receptors. Cell. Signal. 10:543-551.

41. Baker, S., and Reddy, E. 1998. Modulation of life and death by the TNF receptor superfamily. Oncogene. 17:3261-3270.

42. Laporte, J.D., et al. 1999. Role of ERK MAP kinases in responses of cultured human airway smooth muscle cells to IL-1beta. Am. J. Physiol. 277:L943-L951.

43. Xie, W., and Herschman, H.R. 1996. Transcriptional regulation of prostaglandin synthase 2 gene expression by platelet-derived growth factor and serum. J. Biol. Chem. 271:31742-31748.

44. Lu, X., Xie, W., Reed, D., Bradshaw, W., and Simmons, D. 1995. Nonsteroidal antiinflammatory drugs cause apoptosis and induce cyclooxygenases in chicken embryo fibroblasts. Proc. Natl. Acad. Sci. USA. 92:7961-7965.

45. Tsujii, M., and DuBois, R.N. 1995. Alterations in cellular adhesion and apoptosis in epithelial cells overexpressing prostaglandin endoperoxide synthase 2. Cell. 83:493-501.

46. Zablocki, K. 1995. Hyperosmolality stimulates phospholipase A2 activity in rabbit renal medulla and in Madin-Darby Canine Kidney (MDCK) cells. Int. J. Biochem. Cell Biol. 27:1055-1063.

47. Zusman, R, and Keiser, H. 1980. Regulation of prostaglandin E2 synthesis by angiotensin II, potassium, osmolality, and dexamethasone. Kidney Int. 17:277-283.

48. Chan, T.A., Morin, P.J., Vogelstein, B., and Kinzler, K.W. 1998. Mechanisms underlying nonsteroidal antiinflammatory drug-mediated apoptosis. Proc. Natl. Acad. Sci. USA. 95:681-686.

49. Tang, D.G., Porter, A.T., and Honn, K.V. 1997. Critical role of arachidonate lipoxygenases in regulating apoptosis. Adv. Exp. Med. Biol. 407:405-411.

50. Segasothy, M., Samad, S.A., Zulfigar, A., and Bennett, W.M. 1994. Chronic renal disease and papillary necrosis associated with the long-term use of nonsteriodal anti-inflammatory drugs as the sole or predominant analgesic. Am. J. Kidney Dis. 24:17-24.

51. Schlondorff, D. 1993. Renal complications of nonsteroidal anti-inflammatory drugs. Kidney Int. 44:643-653.

52. Molland, E.A. 1978. Experimental renal papillary necrosis. Kidney Int. 13:5-14.

53. Bohman, S. 1974. The ultrastructure of the rat renal medulla as observed after improved fixation methods. J. Ultrastruct. Res. 47:329-360.

54. Roman, R., and Lianos, E. 1990. Influence of prostaglandins on papillary blood flow and pressure-natriuretic response. Hypertension. 15:29-35.

55. Parekh, N., and Zou, A. 1996. Role of prostaglandins in renal medullary circulation: response to different vasoconstrictors. Am. J. Physiol. 271:F653-F658 